\title{
Field Screening of Cowpea Genotypes for Alkaline Soil Tolerance
}

\author{
Ricardo Goenaga ${ }^{2}$ \\ USDA-ARS, Tropical Agriculture Research Station, 2200 P.A. Campos \\ Avenue, Suite 201, Mayaguez, Puerto Rico 00680-5470
}

\author{
A. Graves Gillaspie, Jr. ${ }^{1}$ \\ USDA-ARS, Plant Genetic Resources Conservation Unit, 1109 Experiment \\ Street, Griffin, GA 30223
}

\section{Adolfo Quiles}

USDA-ARS, Tropical Agriculture Research Station, 2200 P.A. Campos Avenue, Suite 201, Mayaguez, Puerto Rico 00680-5470

Additional index words. yield, alkaline soils, grain protein, Vigna unguiculata

\begin{abstract}
Cowpea or Southernpea [Vigna unguiculata (L.) Walp.] is an important legume crop used as a feed for livestock, as a green vegetable, and for consumption of its dry beans, which provide $22 \%$ to $25 \%$ protein. The crop is very sensitive to alkaline soil conditions. When grown at soil pH of 7.5 or higher, cowpea develops severe leaf chlorosis caused by deficiencies of iron $(\mathrm{Fe})$, zinc $(\mathrm{Zn})$, and manganese $(\mathrm{Mn})$ resulting in stunted plant growth and yield reduction. We evaluated in replicated field experiments at St. Croix, U.S. Virgin Islands, and Juana Díaz, Puerto Rico, 24 PIs and two commercial cultivars, some of which have shown some tolerance to alkaline soils in unreplicated, seed regeneration plots of the U.S. cowpea collection. Alkaline soil conditions at St. Croix were too severe resulting in average yield of genotypes at this location being significantly lower and $77 \%$ less than that at Juana Díaz. Nevertheless, some genotypes performed well at both locations. For example, PIs 222756, 214354, 163142, 582605, 582840, 255766, $\mathbf{5 8 2 6 1 0}, \mathbf{5 8 2 6 1 4}, \mathbf{5 8 2 5 7 6}, \mathbf{5 8 2 8 0 9}$, and 349674 yielded in the upper half of the group at both locations. Accession PI 163142 ranked third in grain yield production at both locations and outyielded the iron-chlorosis-resistant controls at St. Croix. These genotypes deserve further attention as potential sources of alkaline soil tolerance.
\end{abstract}

Cowpea (Vigna unguiculata L. Walp.) is an important grain legume crop used as a feed for livestock, as a green vegetable, and its dry beans provide $22 \%$ to $25 \%$ protein (Goenaga et al., 2008; Murillo-Amador et al., 2006). Because of its versatility, high nutrition, and self-pollinating nature, cowpea has been advocated as a candidate crop for space agriculture (Nelson et al., 2008). World production of cowpea was $3.23 \times 10^{6}$ metric tons in 2007 with $93 \%$ of total production originating in African nations (Food and Agriculture Organization, 2009).

Calcareous soils, where cowpea is often grown, cover more than $25 \%$ of the earth's soil surface (Marschner, 2003). When grown at $\mathrm{pH}$ greater than 7.5, cowpea develops severe leaf chlorosis caused by deficiencies of $\mathrm{Fe}, \mathrm{Zn}$,

Received for publication 2 Aug. 2010. Accepted for publication 13 Sept. 2010.

We thank Angel Marrero, Delvis Pérez, and Tomás Miranda for their excellent field and laboratory assistance.

Mention of trade names or commercial products in this publication is solely for the purpose of providing specific information and does not imply recommendation or endorsement of the U.S. Department of Agriculture.

${ }^{1}$ Retired.

${ }^{2}$ To whom reprint requests should be addressed; e-mail Ricardo.Goenaga@ars.usda.gov. and often Mn. To our knowledge, there are no commercial cowpea cultivars possessing alkaline-soil tolerance, but evidence of genotypic differences has been observed (Goenaga, personal observations). For years, seed of photoperiod-sensitive accessions in the U.S. Department of Agriculture (USDA) cowpea collection conserved at Griffin, GA, has been regenerated at the USDA Agricultural Research Service (ARS) facilities in St. Croix, U.S. Virgin Islands (Gillaspie et al., 1999). Genetic diversity for tolerance to alkaline soil conditions such as those encountered at St. Croix has been observed by the authors during these regeneration cycles in field plots with $\mathrm{pH}$ greater than 8.0. Tolerance is defined in this study as the ability of a genotype to produce a good crop when field-grown at a $\mathrm{pH}$ greater than 7.5.

The present study was conducted with the objective of determining yield potential of various cowpea genotypes that have shown alkaline-soil tolerance in unreplicated seed regeneration plots as an effort to identify materials that could be used in cowpea breeding improvement programs.

\section{Material and Methods}

This study was conducted at the USDA, ARS, Germplasm Introduction and Research Unit in St. Croix, U.S. Virgin Islands (fine loamy, carbonatic isohyperthermic Typic Calciustolls) and at the University of Puerto Rico, Juana Díaz, Agricultural Experiment Substation (fine loamy, mixed isohyperthermic Cumulic Haplustoll). Soil and historical climatic characteristics at each site are described in Tables 1 and 2 .

Field experiments in St. Croix were established on 29 Apr. 2005 and 7 Nov. 2006 and in Juana Díaz on 27 Apr. 2005 and 28 Sept. 2006. The phenotypic descriptors and origin of the PIs in the experiment are described in Table 3. The accessions PI 582805 and PI 582850 were included in the study as "very resistant" controls to $\mathrm{Fe}$ chlorosis when grown in alkaline ( $\mathrm{pH}=8.2$ ) soil (USDA-ARS, National Genetic Resources Program, 2010). The commercial cultivars Coronet and Pinkeye Purplehull were used as susceptible controls. The experiments were planted in a randomized complete block design with four replications. Because of the prostate growth habit of some genotypes, experimental plots consisted of 3-m rows spaced $6.1 \mathrm{~m}$ apart. Seedlings were thinned to an

Table 2. Total rainfall and average maximum and minimum temperatures in Juana Díaz, PR, and St. Croix, U.S. Virgin Islands, during the growth experimental period

\begin{tabular}{lccccc}
\hline & \multicolumn{4}{c}{ Location } \\
\cline { 2 - 3 } \cline { 5 - 6 } & \multicolumn{2}{c}{ Juana Díaz } & \multicolumn{2}{c}{ St. Croix } \\
\cline { 2 - 3 } & 2005 & 2006 & & 2005 & 2006 \\
\hline Rainfall $(\mathrm{mm})$ & 580 & 197 & 483 & 246 \\
$\begin{array}{c}\text { Maximum } \\
\text { temperature }\left({ }^{\circ} \mathrm{C}\right)\end{array}$ & 32.6 & 32.2 & 32.6 & 29.9 \\
$\begin{array}{c}\text { Minimum } \\
\text { temperature }\left({ }^{\circ} \mathrm{C}\right)\end{array}$ & 23.3 & 22.1 & 23.7 & 21.9 \\
\hline
\end{tabular}

Table 1. Average preplant soil characteristics at Juana Díaz, PR, and St. Croix, U.S. Virgin Islands, measured to a depth of $20 \mathrm{~cm}$ at the experimental sites.

\begin{tabular}{|c|c|c|c|c|}
\hline \multirow[b]{2}{*}{ Soil characteristics } & \multicolumn{2}{|c|}{ St. Croix } & \multicolumn{2}{|c|}{ Juana Díaz } \\
\hline & 2005 & 2006 & 2005 & 2006 \\
\hline$\overline{\mathrm{pH}}$ in water & 8.3 & 8.2 & 7.9 & 7.9 \\
\hline $\mathrm{pH}$ in calcium chloride & 7.9 & 7.7 & 7.4 & 7.4 \\
\hline Electrical conductivity $\left(\mu \mathrm{S} \cdot \mathrm{cm}^{-1}\right)$ & 295 & 341 & 161 & 155 \\
\hline Ammonium nitrogen $\left(\mathrm{mg} \cdot \mathrm{kg}^{-1}\right)$ & 21 & 40 & 42 & 34 \\
\hline Nitrate nitrogen $\left(\mathrm{mg} \cdot \mathrm{kg}^{-1}\right)$ & 15 & 22 & 28 & 42 \\
\hline Organic carbon $(\%)$ & 1.3 & 1.4 & 0.81 & 0.86 \\
\hline Phosphorus $\left(\mathrm{mg} \cdot \mathrm{kg}^{-1}\right)$ & 148 & 68 & 126 & 124 \\
\hline Potassium $\left(\mathrm{mg} \cdot \mathrm{kg}^{-1}\right)$ & 1301 & 1560 & 1451 & 1417 \\
\hline Calcium $\left(\mathrm{mg} \cdot \mathrm{kg}^{-1}\right)$ & 6269 & 7344 & 3846 & 3856 \\
\hline Magnesium $\left(\mathrm{mg} \cdot \mathrm{kg}^{-1}\right)$ & 243 & 270 & 384 & 379 \\
\hline Bicarbonate (mM) & 5.0 & 2.7 & 3.3 & 3.3 \\
\hline
\end{tabular}


Table 3. Plant and grain phenotypic descriptors ${ }^{\mathrm{z}}$ of 26 cowpea genotypes grown at two locations (Juana Díaz, PR, and St. Croix, U.S. Virgin Islands).

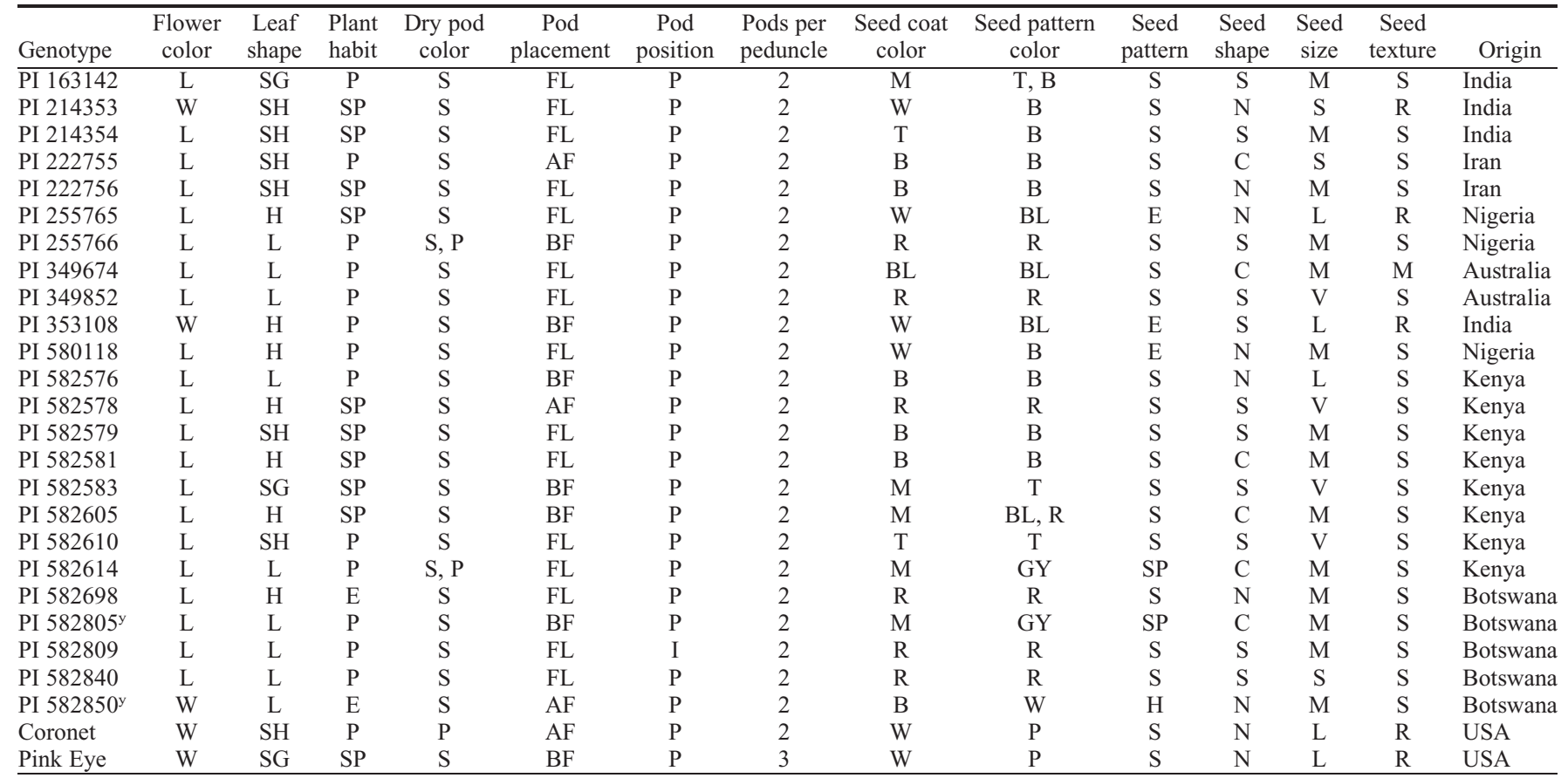

${ }^{2}$ Descriptor coding: Flower color: L (lavender), W (white); Leaf shape: H (hastate), L (lanceolate), SG (subglobose), SH (sub-hastate); Plant habit: E (erect), SP (semiprostrate), P (prostrate); Dry pod color: S (straw), P (purple); Pod placement: AF (above foliage), FL (foliage level), BF (below foliage); Pod position: I (intermediate), P (pendant); Pods per peduncle: actual number; Seed coat color: B (brown), BL (black), M (mixed), R (red), T (tan), W (white/cream); Seed pattern color: Bl (black), B (brown), GY (gray), P (purple), R (red), T (tan), W (white); Seed pattern: E (eye), H (Holstein), S (solid), SP (speckled); Seed shape: C (crowder, seed flat on both ends), S (semicrowder, seed flat on one end and rounded on other), N (noncrowder, seed rounded on both ends); Seed size: L (large), M (medium), S (small), V (variable); Seed texture: R (rough), S (smooth), M (mixed).

${ }^{y}$ Cowpea cultivars reported by USDA-ARS, National Genetic Resources Program (2010) to be resistant to iron chlorosis.

Table 4. Average yield, weight of 100 seed, seed protein, midbloom, maturity, plant height, and pod length of 26 cowpea genotypes in field experiments conducted at Juana Díaz (JD), PR, and St. Croix (SC), U.S. Virgin Islands, in 2005 and 2006.

\begin{tabular}{|c|c|c|c|c|c|c|c|c|c|c|c|c|c|c|}
\hline \multirow[b]{2}{*}{ Genotype } & \multicolumn{2}{|c|}{ Yield $\left(\mathrm{kg} \cdot \mathrm{ha}^{-1}\right)$} & \multicolumn{2}{|c|}{ 100-seed wt (g) } & \multicolumn{2}{|c|}{ Seed protein $(\%)$} & \multicolumn{2}{|c|}{ Midbloom (d) } & \multicolumn{2}{|c|}{ Maturity (d) } & \multicolumn{2}{|c|}{ Plant ht $(\mathrm{cm})$} & \multicolumn{2}{|c|}{ Pod length $(\mathrm{cm})$} \\
\hline & JD & $\mathrm{SC}$ & JD & $\mathrm{SC}$ & JD & $\mathrm{SC}$ & JD & $\mathrm{SC}$ & JD & $\mathrm{SC}$ & JD & $\overline{\mathrm{SC}}$ & JD & $\mathrm{SC}$ \\
\hline PI 163142 & 851.4 & 269.6 & 12.3 & 9.2 & 24.4 & 24.0 & 45.2 & 58.7 & 62.4 & 97.8 & 49.0 & 26.7 & 16.7 & 12.0 \\
\hline PI 214353 & 347.5 & 255.9 & 9.8 & 7.4 & 24.0 & 23.6 & 41.6 & 51.0 & 55.7 & 73.8 & 48.9 & 37.2 & 13.7 & 11.9 \\
\hline PI 214354 & 683.7 & 282.9 & 10.2 & 8.9 & 25.6 & 25.5 & 39.9 & 55.0 & 60.1 & 74.7 & 49.2 & 44.2 & 14.8 & 15.1 \\
\hline PI 222755 & 490.8 & 38.0 & 7.1 & 5.0 & 21.5 & 22.6 & 43.4 & 65.2 & 62.4 & 89.0 & 51.7 & 25.6 & 12.4 & 8.9 \\
\hline PI 222756 & 713.7 & 386.5 & 9.5 & 8.8 & 25.2 & 25.1 & 41.0 & 53.4 & 55.9 & 75.9 & 54.1 & 39.0 & 16.2 & 14.8 \\
\hline PI 255765 & 314.8 & 44.3 & 14.7 & 7.6 & 25.5 & 26.4 & 33.6 & 56.2 & 50.5 & 91.0 & 43.0 & 14.1 & 16.6 & 8.0 \\
\hline PI 255766 & 753.0 & 177.3 & 10.8 & 6.4 & 24.6 & 26.6 & 39.9 & 62.4 & 54.0 & 89.0 & 49.7 & 21.5 & 18.6 & 11.0 \\
\hline PI 349674 & 1035.7 & 115.5 & 10.4 & 3.6 & 24.7 & 25.5 & 53.2 & 84.7 & 68.4 & 108.0 & 60.7 & 16.7 & 16.6 & 6.9 \\
\hline PI 349852 & 543.1 & 101.2 & 11.2 & 7.3 & 26.3 & 28.0 & 73.5 & 100.5 & 88.1 & 128.8 & 49.4 & 31.2 & 14.9 & 10.6 \\
\hline PI 353108 & 413.7 & 71.1 & 12.3 & 6.0 & 25.5 & 27.3 & 35.1 & 56.5 & 51.1 & 85.7 & 38.6 & 13.9 & 16.3 & 7.9 \\
\hline PI 580118 & 125.6 & 82.2 & 5.9 & 4.3 & 25.6 & 26.3 & 83.8 & 74.2 & 100.1 & 101.7 & 26.9 & 9.0 & 9.9 & 6.7 \\
\hline PI 582576 & 727.0 & 126.6 & 16.1 & 8.3 & 24.2 & 26.6 & 40.2 & 62.5 & 54.9 & 89.5 & 39.6 & 16.9 & 19.8 & 9.1 \\
\hline PI 582578 & 518.0 & 101.0 & 12.6 & 10.1 & 22.1 & 23.2 & 43.8 & 52.3 & 60.0 & 81.4 & 42.7 & 27.0 & 15.9 & 12.3 \\
\hline PI 582579 & 451.2 & 140.9 & 11.0 & 6.5 & 23.8 & 26.7 & 40.4 & 55.6 & 53.7 & 86.0 & 38.9 & 22.7 & 15.4 & 9.9 \\
\hline PI 582581 & 788.1 & 107.5 & 8.4 & 4.3 & 24.1 & 24.6 & 41.4 & 58.0 & 55.9 & 92.0 & 46.5 & 18.0 & 13.7 & 6.9 \\
\hline PI 582583 & 599.5 & 103.5 & 13.2 & 9.4 & 23.8 & 25.2 & 39.7 & 56.2 & 53.6 & 81.5 & 39.1 & 22.4 & 17.4 & 12.2 \\
\hline PI 582605 & 755.5 & 258.0 & 11.2 & 8.4 & 22.9 & 24.5 & 42.5 & 56.5 & 61.0 & 82.8 & 47.4 & 31.2 & 16.7 & 12.3 \\
\hline PI 582610 & 824.0 & 161.7 & 10.1 & 6.1 & 25.7 & 25.8 & 41.7 & 55.8 & 55.7 & 82.8 & 44.0 & 23.0 & 14.2 & 9.1 \\
\hline PI 582614 & 620.1 & 161.0 & 9.1 & 4.8 & 25.3 & 25.3 & 40.0 & 57.0 & 54.3 & 85.2 & 42.1 & 24.1 & 14.9 & 9.6 \\
\hline PI 582698 & 198.5 & 66.4 & 8.6 & 8.8 & 26.6 & 28.5 & 34.4 & 47.0 & 50.1 & 70.2 & 35.6 & 31.7 & 16.3 & 16.4 \\
\hline PI $582805^{y}$ & 989.9 & 91.5 & 9.0 & 4.3 & 25.2 & 25.4 & 65.1 & 69.7 & 82.7 & 98.5 & 35.6 & 13.2 & 11.7 & 5.8 \\
\hline PI 582809 & 812.7 & 122.1 & 9.1 & 5.4 & 22.6 & 23.0 & 51.2 & 90.8 & 68.5 & 125.0 & 41.2 & 16.7 & 10.2 & 6.3 \\
\hline PI 582840 & 778.6 & 256.8 & 7.6 & 4.3 & 23.1 & 22.6 & 66.5 & 75.6 & 81.9 & 115.6 & 43.0 & 19.7 & 9.4 & 6.1 \\
\hline PI $582850^{y}$ & 219.4 & 45.0 & 9.7 & 3.4 & 22.9 & 22.4 & 39.6 & 54.3 & 53.4 & 84.7 & 41.4 & 12.0 & 14.4 & 6.1 \\
\hline Coronet & 567.8 & 44.0 & 15.6 & 5.4 & 24.1 & 25.6 & 36.2 & 63.0 & 52.7 & 96.7 & 38.0 & 10.4 & 15.7 & 5.9 \\
\hline Pinkeye purplehull & 445.6 & 35.5 & 15.6 & 4.6 & 23.1 & 22.6 & 37.1 & 59.5 & 54.6 & 90.0 & 39.1 & 8.9 & 16.3 & 4.3 \\
\hline Average & 598.8 & 140.3 & 10.8 & 6.5 & 24.3 & 25.3 & 45.6 & 61.4 & 61.5 & 88.1 & 43.7 & 22.2 & 15.0 & 9.4 \\
\hline $\operatorname{LSD}(0.05)^{\mathrm{z}}$ & 158.2 & 133.2 & 0.90 & 3.2 & 0.99 & 3.0 & 6.1 & 5.8 & 6.6 & 5.6 & 0.90 & 10.2 & 1.3 & 4.1 \\
\hline Year (Y) & $* *$ & * & ** & $* * *$ & NS & NS & $* * *$ & NS & $* * *$ & NS & $*$ & $* *$ & ** & $* *$ \\
\hline Genotype (G) & $* * *$ & $* * *$ & $* * *$ & $* * *$ & $* * *$ & $* * *$ & $* * *$ & $* * *$ & $* * *$ & $* * *$ & $* * *$ & $* * *$ & $* * *$ & $* * *$ \\
\hline$G \times Y$ & $* * *$ & NS & $* * *$ & $* * *$ & $* * *$ & NS & $* * *$ & $* * *$ & $* * *$ & $* * *$ & $* * *$ & $* *$ & $* * *$ & *** \\
\hline Location (L) & $* * *$ & & *** & & & NS & & $* * *$ & $* * *$ & & $* * *$ & & & **** \\
\hline $\mathrm{L} \times \mathrm{G}$ & $* * *$ & & $* * *$ & & & NS & & $* * *$ & $* * *$ & & $* * *$ & & & *** \\
\hline
\end{tabular}

${ }^{\mathrm{z}}$ Least significant difference at $P=0.05$.

${ }^{\mathrm{y}}$ Cowpea cultivars reported by USDA-ARS, National Genetic Resources Program (2010) to be resistant to iron chlorosis.

Ns, ***, **, *Non-significant or significant at $P \leq 0.001,0.01$, or 0.05 , respectively. 
in-row spacing of $15 \mathrm{~cm}$. Fertilization was provided 1 month after planting using a $15 \mathrm{~N}-$ $2.2 \mathrm{P}-8.3 \mathrm{~K}$ commercial mixture at a rate of $138 \mathrm{~kg} \cdot \mathrm{ha}^{-1}$. Plants were drip-irrigated at both locations as necessary. Midbloom and maturity were determined as the number of days after planting at which $50 \%$ of plants flowered and the first dry pod appeared, respectively. Pods were harvested by hand as they matured, dried at $38{ }^{\circ} \mathrm{C}, 25 \%$ relative humidity, and shelled. Seed yield was then determined by extrapolating total plot seed weight to a per-hectare basis. Plant height was measured with a ruler at midrow. Pod length was determined by averaging the length of 10 mature pods from each of five plants selected randomly from each plot. Random 100-seed samples from each experimental unit were weighed to determine seed weight. Seed nitrogen was determined using the micro-Kjeldahl procedure and multiplied by the factor 6.25 to obtain percent seed protein (Association of Official Analytical Chemists, 2000).

Soil from each block was sampled $\approx 3$ weeks before planting by taking a boring at a depth of 0 to $20 \mathrm{~cm}$ from each cultivar row. Samples were air-dried and passed through a 20-mesh screen. Soil pH in water and $0.01 \mathrm{M}$ $\mathrm{CaCl}_{2}$ (1:2 soil: water) were measured with a glass electrode. Exchangeable cations [potassium, magnesium, calcium $(\mathrm{Ca}), \mathrm{Mn}$ ] were extracted with neutral $1 \mathrm{~N} \mathrm{NH}_{4} \mathrm{OAc}$ and determined by atomic absorption spectroscopy. Phosphorus was determined by extracting with $\mathrm{pH} 8.5$ sodium bicarbonate and determined using the ascorbic acid method (Sparks, 1996). Organic carbon was determined by the Walkley-Black method (Sparks, 1996). Soil electrical conductivity was determined with a conductivity meter (Thermo Scientific Orion 3-Star, Beverly, MA) using $20 \mathrm{~g}$ of soil in 40 $\mathrm{mL}$ distilled water. Soil ammonium and nitrate were determined by steam distillation. Bicarbonate was determined in a saturated soil paste by titrating with $0.05 \mathrm{~N}$ sulfuric acid standardized with $0.01 \%$ methyl orange indicator (USDA-NRCS, 1996).

Analysis of variance was carried out using the GLM procedure of SAS (Release 9.1 for Windows; SAS Institute, Cary, NC). After significant $\mathrm{F}$ tests at $P<0.05$, mean separation was performed using the least significant difference test.

\section{Results and Discussion}

Location, year, and genotypes showed significant effects $(P \leq 0.05)$ on most crop parameters measured in the study. An exception was seed protein, which did not show a significant year and location effect. The genotype $\times$ location interaction was significant for yield, 100-seed weight, days to midbloom and maturity, plant height, and pod length but not for seed protein (Table 4).

Year and location had a significant effect on yield of cowpea genotypes (Table 4). Average yield of genotypes at St. Croix was significantly lower than at Juana Díaz (Table 4). A possible explanation on the cause of this average yield reduction at St. Croix may be that the plot used in 2005 had a higher soil bicarbonate level than the plot used in 2006 (Table 1). Bicarbonate is regarded as a major causal factor for $\mathrm{Fe}$ and $\mathrm{Zn}$ deficiency in many crop species grown in calcaceous soil (Cartmill et al., 2007; De la Guardia and Alcántara, 2002; Mengel et al., 1984; Nikolic and Römheld, 1999; Valdez-Aguilar and Reed, 2010; Yang et al., 1994). Indeed, very severe leaf chlorosis was observed in plants grown at St. Croix in 2005. For several genotypes, seed germinated but plants grew poorly afterward and eventually died or became stunted without producing pods. The experimental area used at St. Croix in 2006 had a lower bicarbonate level, but soil $\mathrm{Ca}$ concentration remained high (Table 1). Leaf chlorosis was also evident in 2006 at St. Croix but not as severe as in 2005. Most probably, lime-induced chlorosis (Marschner, 2003) was also a factor in causing lower cowpea yield at St. Croix than at Juana Díaz.

Average yield of genotypes at Juana Diaz was significantly lower in 2006 than in 2005 (Table 5). This response was probably the result of genotypes responding to decreasing day length after planting late in the year in 2006 (Eriksen and Whitney, 1984). Midbloom in fact occurred $\approx 16 \mathrm{~d}$ later in 2006 than in 2005 (data not shown). A similar yield response was not observed at St. Croix possibly because of the extremely low yields obtained in 2005 caused by very adverse soil chemical properties.

PIs 222756, 214354, 163142, 582605, 582840, 255766, 582610, 582614, 582576, 582809 , and 349674 yielded in the upper half of the group at both locations with average yield of 752 and $220 \mathrm{~kg} \cdot \mathrm{ha}^{-1}$, respectively, at Juana Díaz and St. Croix. Although these yields are not high (less than $1500 \mathrm{~kg} \cdot \mathrm{ha}^{-1}$ ), the high soil $\mathrm{pH}$ along with other adverse soil characteristics (Table 1) in which these genotypes were grown may warrant further studies by breeders interested in developing cowpea cultivars with alkaline soil tolerance. For example, accession PI 349674 yielded among the upper half of the genotypes at St. Croix and was the best yielder $\left(1036 \mathrm{~kg} \cdot \mathrm{ha}^{-1}\right)$ at Juana Díaz. Accession PI 163142 ranked third at both locations suggesting a high degree of alkaline soil tolerance (Table 4). The chlorosis-resistant genotypes, PI 582805 and PI 582850, performed very poorly at St. Croix with average yield of $68 \mathrm{~kg} \cdot \mathrm{ha}^{-1}$; at Juana Diaz, only PI 582805 showed an acceptable yield (Table 4).

As an important staple in many developing areas of the world, particularly the semiarid tropics where alkaline soils are common, it is important to identify not only high-yielding cowpea genotypes, but also those having high seed protein content. At both locations, genotypes PI 582698 and PI 349852 had high seed protein concentration; however, grain yield in these genotypes was low (Table 4). A negative correlation between cowpea grain yield and seed protein concentration has also been found in previous studies with cowpea by the authors (Goenaga et al., 2008).

Seed weight varied significantly among genotypes and locations (Table 4). At Juana
Table 5. Yield $\left(\mathrm{kg} \cdot \mathrm{ha}^{-1}\right)$ of 26 cowpea genotypes grown in Juana Díaz, PR (JD), and Saint Croix, U.S. Virgin Islands (SC), during 2 planting years.

\begin{tabular}{|c|c|c|c|c|}
\hline \multirow[b]{2}{*}{ Genotype } & \multicolumn{2}{|c|}{2005} & \multicolumn{2}{|c|}{2006} \\
\hline & JD & $\mathrm{SC}$ & JD & $\mathrm{SC}$ \\
\hline$\overline{\text { PI } 163142}$ & 1310.8 & 112.8 & 392.0 & 426.5 \\
\hline PI 214356 & 429.5 & 160.8 & 265.6 & 351.0 \\
\hline PI 214354 & 1142.2 & 98.4 & 225.1 & 467.4 \\
\hline PI 222755 & 720.7 & 0.91 & 260.8 & 76.7 \\
\hline PI 222756 & 1064.2 & 254.1 & 363.1 & 519.0 \\
\hline PI 255765 & 393.3 & 0 & 236.3 & 88.6 \\
\hline PI 255766 & 1203.3 & 3.6 & 302.6 & 351.1 \\
\hline PI 349674 & 1622.0 & 0 & 449.4 & 230.9 \\
\hline PI 349852 & 681.8 & 71.8 & 404.4 & 130.5 \\
\hline PI 353108 & 655.5 & 0 & 171.9 & 142.2 \\
\hline PI 580118 & 6.8 & 0 & 244.4 & 164.4 \\
\hline PI 582576 & 1212.3 & 0 & 241.7 & 253.2 \\
\hline PI 582578 & 795.5 & 11.6 & 240.5 & 190.5 \\
\hline PI 582579 & 719.7 & 1.5 & 182.7 & 280.3 \\
\hline PI 582581 & 1188.5 & 0 & 387.6 & 215.0 \\
\hline PI 582583 & 1028.4 & 13.7 & 170.5 & 193.4 \\
\hline PI 582605 & 1124.5 & 12.3 & 386.5 & 503.7 \\
\hline PI 582610 & 1322.8 & 14.3 & 325.2 & 309.1 \\
\hline PI 582614 & 933.2 & 24.1 & 307.0 & 297.9 \\
\hline PI 582698 & 304.3 & 57.8 & 92.7 & 75.0 \\
\hline PI 582805y & 1736.9 & 0 & 242.8 & 182.9 \\
\hline PI 582809 & 1388.7 & 19.2 & 236.8 & 225.1 \\
\hline PI 582840 & 1360.3 & 339.9 & 196.8 & 173.6 \\
\hline PI 582850y & 209.1 & 0 & 229.7 & 90.0 \\
\hline Coronet & 792.1 & 0 & 343.5 & 88.1 \\
\hline $\begin{array}{l}\text { Pinkeye } \\
\text { Purplehull }\end{array}$ & 533.5 & 0 & 357.6 & 71.0 \\
\hline Average & 918.4 & 46.0 & 279.1 & 234.5 \\
\hline $\operatorname{LSD}(0.05)^{\mathrm{z}}$ & 337.2 & NS & 93.5 & 165.0 \\
\hline
\end{tabular}

${ }^{\mathrm{z}}$ Least significant difference at $P=0.05$.

${ }^{y}$ Cowpea cultivars reported by USDA-ARS, National Genetic Resources Program (2010) to be resistant to iron chlorosis.

NS $=$ non-significant.

Díaz, genotypes PI 582576 and cultivars Coronet and Pinkeye Purplehull had the highest 100 -seed weight averaging $15.8 \mathrm{~g}$. Significantly lower 100-seed weight was found in genotypes grown at St. Croix because of poor plant development that resulted from adverse soil characteristics.

Midbloom mean for all genotypes was $46 \mathrm{~d}$ at Juana Díaz and $61 \mathrm{~d}$ at St. Croix (Table 4). At both locations, the accessions PI 349852 , 582809, 349674, 582840, 580118, and 582805 took significantly longer to attain midbloom and reach maturity than other genotypes. Accession PI 582698 attained midbloom and maturity sooner than the rest of the genotypes at both locations (Table 4). At Juana Díaz, the accessions PI 349674 and PI 222756 were significantly taller than the rest of the genotypes averaging $57.4 \mathrm{~cm}$ in height, whereas at St. Croix accessions PI 214354 and 222756 were significantly taller than the rest averaging $41.6 \mathrm{~cm}$ in height. Pod size of all genotypes was significantly longer at Juana Díaz than at St. Croix (Table 4). The fact that average plant height and pod length at St. Croix were, respectively, $50 \%$ and $37 \%$ lower than at Juana Díaz is indicative that soil properties at St. Croix were a limiting factor for adequate growth and development of plants. In a multisite experiment seeking to identify suitable seed regeneration sites for cowpea germplasm, it was found that mean seed production at $\mathrm{St}$. Croix was 40 times less than at Isabela, Puerto Rico. This difference was attributed to a very 
high soil $\mathrm{pH}$, which limited plant growth at $\mathrm{St}$. Croix (Gillaspie et al., 1999).

In conclusion, the chemical properties of the soil at St. Croix, particularly in Year 1, proved to be beyond the threshold for adequate cowpea growth and development. Nevertheless, despite the harsh soil environment encountered at St. Croix, there were gentoypes (e.g., PIs 222756, 214354, 163142) that outperformed chlorosis-resistant genotypes for grain yield and plant height (i.e., growth) and deserve further attention as potential sources for alkaline soil tolerance. Furthermore, accession PI 163142 performed well at both locations and deserves attention in future studies.

\section{Literature Cited}

Association of Official Analytical Chemists. 2000. Official methods of analysis of AOAC International. Vol. 1: Agricultural Chemicals: Contaminants; drugs, p. 29-30c. In: Horwitz, W. (ed.). AOAC official method 2001.11 protein (crude) in animal feed, forage (plant tissue), grain, and oilseeds. AOAC International, Gaithersburg, MD.

Cartmill, A.D., A. Alarcón, and L.A. ValdezAguilar. 2007. Arbuscular mycorrhizal fungi enhance tolerance of Rosa multiflora cv. Burr to bicarbonate in irrigation water. J. Plant Nutr. 30:1517-1540.
De la Guardia, M.D. and E. Alcántara. 2002. Bicarbonate and low iron level increase root to total plant weight ratio in olive and peach rootstock. J. Plant Nutr. 25:1021-1032.

Eriksen, F.I. and A.S. Whitney. 1984. Effects of solar radiation regimes on growth and N2 fixation of soybean, cowpea and bushbean. Agron. J. 76:529-535.

Food and Agriculture Organization. 2009. FAOSTAT Statistics Database 2007. 30 Nov. 2009. <http:// faostat.fao.org/site/567/default.aspx\#ancor>.

Gillaspie A.G., Jr., R. Goenaga, S. Torres, and E. Peregrine. 1999. Identification of suitable seed regeneration sites for photoperiod-sensitive cowpea germplasm. Crop Sci. 39:1513-1515.

Goenaga, R., A.G. Gillaspie, and A. Quiles. 2008. Assessing yield potential of cowpea genotypes grown under virus pressure. HortScience 43: 673-676.

Marschner, H. 2003. Mineral nutrition of higher plants. Academic Press, London, UK.

Mengel, K., M.T. Breininger, and W. Bübl. 1984. Bicarbonate, the most important factor inducing iron chlorosis in vine grapes on calcareous soil. Plant Soil 81:333-344.

Murillo-Amador, B., E. Troyo-Diéguez, J.L. GarcíaHernández, R. López-Aguilar, N.Y. ÁvilaSerrano, S. Zamora-Salgado, E.O. RuedaPuente, and C. Kaya. 2006. Effect of $\mathrm{NaCl}$ salinity in the genotypic variation of cowpea (Vigna unguiculata) during early vegetative growth. Sci. Hort. 108:423-431.
Nelson, M., W.F. Dempster, J.P. Allen, S. Silverstone, A. Alling, and M. van Thillo. 2008. Cowpeas and pinto beans: Performance and yields of candidate space crops in the laboratory biosphere closed ecological system. Adv. Space Res. 41:748-753.

Nikolic, M. and V. Römheld. 1999. Mechanism of Fe uptake by the leaf symplast: Is Fe inactivation in leaf a cause of Fe deficiency chlorosis? Plant Soil 215:229-237.

Sparks, D.L. (ed.). 1996. Methods of soil analysis. Part 3. Chemical methods. SSSA Book Series 5. SSSA and ASA, Madison, WI.

USDA-ARS, National Genetic Resources Program. 2010. Germplasm Resources Information Network (GRIN) [online database]. National Germplasm Resources Laboratory, Beltsville, MD, 22 July 2010. <http://www.ars-grin.gov/ cgi-bin/npgs/html/eval.pl?493889>.

USDA-NRCS. 1996. Soil survey laboratory methods manual. Soil survey investigations report No. 42, Version 3.0.

Valdez-Aguilar, L. and D.W. Reed. 2010. Growth and nutrition of young bean plants under high alkalinity as affected by mixtures of ammonium, potassium and sodium. J. Plant Nutr. 33: 1472-1488.

Yang, X., V. Römheld, and M. Marschner. 1994. Effect of bicarbonate on root growth and accumulation of organic acids in $\mathrm{Zn}$-inefficient and $\mathrm{Zn}$-efficient rice cultivars (Oryza nativa L.). Plant and Soil 164:1-7. 